\title{
Impact Of Foreign Direct Investment On India's Exports
}

\author{
Dr. SumanMakkar, \\ Associate Professor in Economics, Panjab University, Chandigarh 160014
}

\begin{abstract}
-
Globalization had major impact on overall trade of the Indian economy. The easy going and conservative attitude of the policy makers in India were shaken by the 1990-91 crisis. The New Economic Policy of the nineties aimed at opening up the economy, to encourage free trade and competition and reduce the role of government in foreign trade matters. Restrictions on international trade were removed, foreign investments were allowed and a new Liberalized Exchange Rate Management System (LERMS) was introduced to reap the benefits of competition and counter the disadvantages of an inward looking trade policy.

Enabled by increasingly liberal policy frameworks, made possible by technological advances, globalization more and more shapes today's world economy. Global trade and foreign direct investment, the two main drivers of this process have undergone a tremendous change during the last two and a half decades. There have been marked shifts in their flows, destinations, determinants and policies. In this process, developing countries have found their economic activities being increasingly internationalized. FDI by TNCs (Transnational Corporations) now plays a major role in linking may national economies, building an integrated international production system - the productive core of the globalized world.
\end{abstract}

Key Word: Globalization, Foreign Direct Investment, Exports, India, MNCs

\section{Council for Innovative Research}

Peer Review Research Publishing System

Journal: International Journal of Management \& Information Technology

Vol. 9, No.3

editor@cirworld.com

www.cirworld.com, member.cirworld.com 


\section{INTRODUCTION}

Enabled by increasingly liberal policy frameworks, made possible by technological advances, globalization more and more shapes today's world economy. Global trade and foreign direct investment, the two main drivers of this process have undergone a tremendous change during the last two and a half decades. There have been marked shifts in their flows, destinations, determinants and policies. In this process, developing countries have found their economic activities being increasingly internationalized. FDI by TNCs (Transnational Corporations) now plays a major role in linking may national economies, building an integrated international production system - the productive core of the globalized world.

Foreign Direct Investment (FDI) plays a pivotal role in the process of economic development particularly in a capital scarce country, where the domestic base of assets like technology, skills and entrepreneurship are quite limited. FDI is treated as one of the main accelerates of economic growth and technological development which provides ample opportunities in accelerating economic development. It provides financial resources for investment in the host country and thereby augments domestic saving efforts. FDI provides the much needed foreign exchange to help in bridging the balance of payment or trade deficit. FDI brings complementary assets such as technology, management and organizational competencies and there are spillover effects of these assets on the rest of the economy. FDI contributes to exports indirectly and an enhanced export possibility contributes to the growth of the host economies by relaxing demand side constraints on economic growth.

\section{OBJECTIVE \& METHODOLOGY}

The present study aims to examine statistically the impact of FDI on Export Promotion in India using Multiple Regression Model and step wise regression analysis for the period 1981-2012.

\section{FOREIGN DIRECT INVESTMENT AND EXPORTS:}

Foreign Direct Investment in export promotion depends upon the motive of investment. If the motive is to capture domestic market because of high trade costs or tariffs, Foreign Direct Investment may not improve the export growth. On the other hand, if the motive of Foreign Direct Investment is to make use of cheap inputs or the countries "comparative advantage to tap the export market, it may contribute to export growth. Inward Foreign Direct Investment contributes to productivity growth which in turn helps increase trade. Recent studies have tried to categories the impact of Foreign Direct Investment, on exports in terms of the following investment motives of the Foreign Direct Investment:-

- $\quad$ Resource - seeking Foreign Direct Investment

- Efficiency - seeking Foreign Direct Investment

- $\quad$ Export - oriented seeking Foreign Direct Investment]

- Market seeking Foreign Direct Investment

- Technology - seeking Foreign Direct Investment

In the case of export-oriented investment, and as trade and investment barriers fall, such investments become increasingly important compared to those that are made first to service the domestic market of the host countries, increasing the likelihood of positive effects of Foreign Direct Investment on trade.

\section{REVIEW OF LITERATURE}

The literature on Foreign Direct Investment and exports reveal a positive relationship (Blomstorm, Kokko and Zejan (1994)43. De Mello (1999)44, UNCTAD (1999)45, Majumdar and Chibbor (1998)46 and Lipsey (1999)47. It has also been debated in literature that export - oriented industries help domestic industries and therefore, crowd - in domestic investment Actken and Harrison (1999)48 opined that MNCs, which bring Foreign Direct Investment into the host country, are larger than domestic firms, pay higher wages, have higher productivity care highly capital intensive and are more likely to contribute to exports due to their international exposure and competitiveness.

However, the study by Sharma (2000)49 finds no effect of Foreign Direct Investment on the exports in the Indian case. Aggarwal (2001)50 finds weak effects support for the hypothesis that foreign firms perform better in exports than local firms. Actken et al (1997) show the positing impact on exports of Foreign Direct Investment using the example of Bangladesh where entry if a single Korean MNC in the garment industry led to the establishment of a number of domestic firms exporting garments creating a large export industry. Sharma (2000) empirically establishes that Foreign Direct Investment does not affect export in the Indian context.

Overall, there is no unamity among the economists regarding the impact of Foreign Direct Investment on exports.

\section{STATISTICAL ESTIMATION OF THE REGRESSION MODEL}

An attempt has been made in the present study to examine the role of Foreign Direct Investment in export promotion in India using Multiple regression Model and step-wise regression analysis for the period 1981-2012. The following regression equation has been estimated:- 
Model:-

$X / Y=a_{0}+a_{1} F D I / Y+a_{2} G D C F / Y+a_{3} I N F+a_{4} G 1+a_{5} E D / X+\mu$

Where

$\mathrm{X} / \mathrm{Y}=$ Exports as a percentage of GDP.

$\mathrm{FDI} / \mathrm{Y}=$ Foreign direct investment as a \%age of GDP

$\mathrm{GDCF} / \mathrm{Y}=$ Gross domestic capital formation as a percentage of GDP.

INF - Annual \%age change in Implicit GDP deflator

G1-Per capita Income

ED/X-External Debt as a ratio to exports

$\mu$-disturbance term (stochastic error term)

Following economic theory, we test the following hypotheses:

- An increase in Foreign Direct Investment promotes export as well.

- A high rate of gross domestic capital formation is an indicator of good developmental potential in future. This suggests a positive influence on export promotion.

- A high rate of inflation is a sign of internal economic tension and the Central Bank to balance the budget and to restrict money supply. As a rule, the higher the rate of inflation, lower the exports. A negative relationship is hypothesized.

- Per capita GDP shows the level of economic development but as well the purchasing power of the people. A higher purchasing power of the people proxied for domestic demand will leave the less resources for exports.

- External debt as a ratio to exports is the ratio of the amount of outstanding external debt of a country at the end of a particular year and the exports of that year. It is a variable that represents the debt burden of the country and hence revealing pressure on foreign exchange reserves.

Besides above there are other variables which are important determinants of export promotion, such as market size, infrastructure tariff level, literacy rate, political risks and legal issues etc.

But out prime focus is to examine the impact of Foreign Direct Investment on exports.

The estimated regression coefficients for the Indian economy for the period 1981-2012 have been presented in Table 1. Table 2 presents correlation matrix for the variables undertaken in the study.

Table 1: Estimated regression coefficients of the regression model on the impact of Foreign Direct Investment and other determinants on exports

$\mathrm{X} / \mathrm{Y}=4.749+0.825 \mathrm{FDI} / \mathrm{Y}+0.397 \mathrm{GDCF} / \mathrm{Y}-0.339 \mathrm{INF}-0.407 \mathrm{ED} / \mathrm{X}-0.001 \mathrm{G}_{1}$
$(11.848)^{\star *}$
$(6.851)^{\star \star}$
(4.041)
(2.020)
(2.372)

$R^{2}=0.68$

$\overline{\mathrm{R}^{2}}=0.66$

$\mathrm{DW}=1.19$

** significant at 99 percent level

Figures in parenthesis denotes t-values

Table2: Correlation Matrix

\begin{tabular}{|l|l|l|l|l|l|l|l|}
\hline & & $\begin{array}{l}\text { Exports } \\
\% \text { of } \\
\text { GDP }\end{array}$ & $\begin{array}{l}\text { Implicit } \\
\text { GDP } \\
\text { deflator }\end{array}$ & $\begin{array}{l}\text { FDI \% } \\
\text { of GDP }\end{array}$ & $\begin{array}{l}\text { Total debt } \\
\text { outstanding and } \\
\text { disbursed as } \\
\text { ratio of exports }\end{array}$ & $\begin{array}{l}\text { Gross } \\
\text { domestic } \\
\text { capital } \\
\text { formation } \\
\text { of GDP }\end{array}$ & $\begin{array}{l}\text { Per } \\
\text { capita } \\
\text { GDP } \\
\text { GR }\end{array}$ \\
\hline Pearson & Export \% GDP & 1.000 & -.764 & .825 & -.801 & .631 & .198 \\
\hline
\end{tabular}




\begin{tabular}{|l|l|l|l|l|l|l|l|}
\hline correlation & $\begin{array}{l}\text { Implicit GDP } \\
\text { deflator }\end{array}$ & -.764 & 1.000 & -.740 & .866 & -.455 & -.416 \\
\cline { 2 - 8 } & FDI \% of GDP & .825 & -.740 & 1.000 & -.769 & .338 & .241 \\
\hline & $\begin{array}{l}\text { Total debt } \\
\text { outstanding and } \\
\text { disbursed as } \\
\text { ratio of exports }\end{array}$ & -.801 & .866 & -.769 & 1.000 & -.476 & -.383 \\
\hline $\begin{array}{l}\text { Gross domestic } \\
\text { capital formation } \\
\% \text { of GDP }\end{array}$ & .631 & -.455 & .338 & -.476 & 1.000 & .406 \\
\cline { 2 - 8 } & $\begin{array}{l}\text { Per capita GDP } \\
\text { GR }\end{array}$ & .198 & -.416 & .241 & -.383 & .406 & 1.000 \\
\hline
\end{tabular}

\section{RESULTS}

Our results show that the model explains 66 percent of the variance. All the coefficients have theoretically expected sign. The latter results supports the conclusion of Lall and Mohammad (1985) ${ }^{51}$ and Majumdar and Chhibar (1998) and might suggest that there is positive and significant association between export and foreign owned firms. Another significant variable is GDCF which increases exports.

It may be concluded that inflows of Foreign Direct Investment in developing countries like India have positive impact on the export growth of a country. Inward Foreign Direct Investment contributes to productivity growth which in turn helps to increase trade.

\section{REFERENCES}

[1] Tobin James," liquidity preferences as behaviour towards risk", The Review of Economic Studies, Vol.25, 1985, No 2, pp 65-86.

[2] Markowitz, Harry M.," Portfolio selection efficient diversification of investments, New York, 1959.

[3] Hymer, Stephen H., The international operations of National Firms; A study of direct foreign investment published P.H.D. dissertation, Masacheisatis institute of Technology, 1960.

[4] Kindleberger, Charles, American Business Abroad: six lectures on direct investment, New Hamen, 1969.

[5] Verhan, Raymond (1966): International investment in the product cycle," Quarterly Journal of Economics, 83 (I), 190-207.

[6] During, J.H," Explaining the international direct investment position of countries: Towards a dynamic or development approach," WeltwertschaftlichesArchiv, Vol. 117, 1981, pp. 30-60.

[7] Hein S. (1992): Trade strategy and dependancy hypothesis. A comparism of policy, foreihn investment and economic growth in Latin America and East Asia". Economic development and cultural change 40 (3): 495 521.

[8] Buckly, Peter J. and Mark, C, Casson (1976); The frture of multinational Enterprises," London Macmullan.

[9] Aliber, Robert.Z," Atheory of direcy foreign investment". In changes P. Kindlcberher (ed). The international corporation, Cambridge, Mass 1970,, pp 17-34.

[10] Aharoni, Yair : The foreign investment decision process, Cambridge, Massachersetts, 1966.

[11] Dunning, John $\mathrm{H}$," The determinants of international production" Oxford Economic Papers, Vol. 25, November 1973, pp. 289-336.

[12] Hulln, Stephen and Menday, Max (1992): " The U.K. regional distribution of foreign direct investment; Analysis and determinants," Regional studies, 26(6), 535- 44.

[13] Lucas, Robert, E.B (1993): " On the determinants of direct foreign investment: Evidence from East and Southeast Asia," World Development, 21(3), March, 391- 406.

[14] Wang, Z. and N. Swain: "The determinants of Foreign Direct investment in Transforming Economics: Empirical Evidence from Hungary and China, Weltwirtschartiches, Vol. 129, pp. 359- 381.

[15] Chan, Chunlai (1997)," On the determinants of FDP in developing countries," Working paper, chinese Economics Research Center, University of Adelaide, Australia. 
[16] Castro, Francisco, B (2000): Foreign direct investment in the European periphery: The competitiveness of Portugal, Ph.D. thesis, University of leads, July 2000. URI- http:/www.fep.up.pt/docents/f.castro.

[17] Edwards, S. (1990): " Capital flows, Foreign direct investment, and debt- equity swaps in developing countries," Working paper series Cambridge, M.A: National Bureau of Economic Research.

[18] Asiedu, E (2002)," On the determinants of foreign direct investment developing countries: Is Africa Different? World Development, Vol. 30(1), pp 107-119.

[19] Broadman and Sun (1997).

[20] Compos, Mauro F. and Kinoshita Yuko (2003): " Why does FDI go where it goes? New Evidence from the transition economic," IMF working paper, IMF institutes.

[21] Canes RE (1982): Multinational Enterprises and Economic Analysis, New York, Cambridge, University Press.

[22] Root, Frankin R. and Ahmed A. Ahmed: Empirical determinants of manufacturing direct foreign in vestments developing countries," Economic development and cultural change, Vol.27, July 1979, pp 751-767.

[23] Archinivu, Enrnest U (1990)," Factors motivating foreign direct investment in Malaysia and Taiwan by United States multinational firms," Ann Arbour: University Microfilms international.

[24] Soon, L.Y (1990)," Foreign Direct Investment in ASEAN Kaulalumpur, Malaysian Economic Association.

[25] Vernon, Raymond (1966)," International Trade and International Investment in the product cycle." Quarterly Journal of Economics, 83(I), 190-207.

[26] Munteariu (1991):

[27] UNCTAD, (1998) World Investment Report.

[28] Kumar N. (1994) Multinational Enterprises and Industrial Organization, Sage publications, New Delhi.

[29] Asiedue (2002), op.cit.

[30] Mody, Ashoka, Sushmita, pasgupta and Surbjit Singh (1999)," Japanese multinationals in Asia: Drives and attractors," Oxford Development Studies, Vol. 2, June, pp 149-64.

[31] Lansbury et al. (1996) Foreign direct investment in Central Europe since 1990: An Econometric study," National instite of Economic Review, No 156, pp 104-13.

[32] Kumar, N. (2002): "Infrastructure Availability, Foreign Direct investment in flows and their export orientation: A cross country study Exploration", RIS Discussion Paper, No 26, 2002.

[33] Soon (1990) op.cit.

[34] Blomsform and A.Kokka (2003): "The Economics of Foreign Direct Investment incentives", NBER Working Paper 9489, 2003.Garibaldi, Pietro, Mora, Nada and others (2001)," What moves capital to transition economics", IMF Staff Papers, Vol. 45, Special issue.

[35] Goldberg, Linda S. and charles, D.Kolstad (1995): "Foreign Direct Investment, Exchange rate variability and demand uncertainly", NBER working Paper, 4815, (Cambridge, Massaches, National Bureau of Economic Research.

[36] Lucas, Robert E. BC (1993)," On the determinants of direct foreign investment: Evidence from East and South East Asia", World Development, 21(3), March 391- 406.

[37] Castro (2000) op.cit.

[38] Moore, Michael, O (1993)," Determinants of German Manufacturing Direct Investment 1980- 88, WeltwirtschaftlichedArchiv, 129(I) 120- 38.

[39] Edwards (1990) opcit.

[40] Taylor C.T (2000): "The impact of Host Country Government Policy on US Multinational Investment Decisions", World Economy, Vol. 23, pp 635- 48.

[41] UNTCAD, Effectiveness of Foreign Direct Investment Policy measures, policy note, TO/ B/COM.2/EM.13/2. 